\title{
EFFECTS OF THE SURFACE CRACKS CAUSED BY COAL MINING ON SOIL CHARACTERISTICS AND WHEAT GROWTH IN HUANG-HUAI-HAI PLAIN, CHINA
}

\author{
ZHANG, H.-B. ${ }^{1,2}-$ MA, S.-C. ${ }^{1,2^{*}}-$ DING, C. ${ }^{1,2}-$ WANG, R. ${ }^{1,2}-$ WANG, G.-X. ${ }^{1}-$ HU, W.-Z. ${ }^{1,2}$ \\ ${ }^{1}$ School of Surveying \& Land Information Engineering, Henan Polytechnic University, Jiaozuo \\ 454000, China \\ ${ }^{2}$ Field Scientific Observation and Research Base of Ministry of Land and Resources, Henan \\ Polytechnic University, Jiaozuo 454000, China \\ *Corresponding author \\ e-mail:mashouchen@126.com \\ (Received $7^{\text {th }}$ Jun 2017; accepted $23^{\text {rd }}$ Sep 2017)
}

\begin{abstract}
Coal has provided a great proportion of energy supply for the country. However, coal mining has caused lots of ecological and environmental problems. In this study, a field investigation experiment was conducted in subsided area of Zhaogu coal mine of Jiaozuo Coal Group, Henan Province, China, to explore effect of surface cracks caused by coal mining on the soil characteristics and crop growth. The results showed that during the jointing stage of wheat, the ranges within which the larger crack (C-1) and smaller crack (C-2) caused the effects on both soil water content and soil respiration were $0-60 \mathrm{~cm}$ and 0 $30 \mathrm{~cm}$ from the cracks, respectively. C-1 significantly reduced the activities of soil urease and invertase within $0-60 \mathrm{~cm}$ from the crack but C-2 did not cause significant inhibition on soil enzymes. During the flowing stage of wheat, $\mathrm{C}-1$ and $\mathrm{C}-2$ significantly reduced soil water content, available nitrogen content and soil respiration within $0-60 \mathrm{~cm}$ and $0-30 \mathrm{~cm}$ from the cracks, respectively. The range within which C1 caused inhibition on urease activity was $0-60 \mathrm{~cm}$ while such range for C-2 was $0-30 \mathrm{~cm}$ from the crack. The ranges within which both $\mathrm{C}-1$ and $\mathrm{C}-2$ caused significant inhibition on invertase activity were $0-60$ $\mathrm{cm}$ from the cracks. C-1 and C-2 caused significant inhibition on photosynthesis of wheat within $0-60 \mathrm{~cm}$ and $0-30 \mathrm{~cm}$ from the cracks, respectively. $\mathrm{C}-1$ and $\mathrm{C} 2$ significantly reduced spike number and grain yield within $0-90$ and $0-60 \mathrm{~cm}$ from the cracks, respectively. In conclusion, surface cracks resulted in loss of water and nutrients and reduction in crop yield, which is more serious with lager cracks. Therefore, further studies are needed to address this problem and to find effective measures to resolve it.
\end{abstract}

Keywords: coal mining subsidence; coal mine; characteristics of soil microorganisms; soil water; fertilizer

\section{Introduction}

Coal is the major energy source in China. Coal mining industry in Henan province is ranked the second place in China and its coal output accounts for nearly $10 \%$ of the country's total (Hu et al., 2014a). While the coal mining areas in Henan have provided substantial proportion of energy supply for the country, some ecological and environmental problems have been caused by coal mining, especially underground coal mining, which have become increasingly serious. Underground coal mining leads to large-scale surface settlement, increases the original geomorphological slope and generates a large number of cracks (gaps), causing substantial damage to the ecological environment in the mining areas (Kuang and Deng, 2007; Tripathi et al., 2009). Under the comprehensive interactions of the subsidence disturbance, rain and wind, the loss of water and fertilizer and soil erosion can easily take place in the farmland in the subsided areas, leading to the degeneration of soil quality (Hu et al., 2014b). Furthermore, due to the uneven surface and the distribution of cracks/gaps all over the subsided areas, the 
soil evaporation area and evaporation intensity are not only increased, the farmlands also loss irrigation capacity. Their drought-resisting capabilities are greatly weakened, which, in turn, seriously affects the farmland productivity. Additionally, coal mining also destroys the structure of the water-holding layer of soil and causes a series of problems such as the declined phreatic table, drought well and the death of vegetation etc (Kuang and Deng, 2007). Therefore, to investigate the effects of cracks caused by coal mining on soil characteristics and crop production is of practical significance and theoretical value for reclamation and management of the farmland in coal mining areas.

In the recent years, a large number of studies have been conducted on the damaged farmland in coal mining areas. However, these studies mainly focused on such aspects as the effects of mining subsidence on physicochemical characteristics of soil (Li et al., 2010; Chen et al., 1999; Sadhu et al., 2012), the surface vegetation (Zhou et al., 2009; Quan et al., 2006; Moreno-de las Heras et al., 2008; Brom et al., 2013), quality of farmland (Meng et al., 2009; Martinez et al., 2013; Hossain et al., 2015) and restoration technologies of the damaged farmland (Cheng et al., 2014) etc. While a few studies have been conducted on the mechanisms underlying the formation of cracks/gaps (Wu et al., 2009) and the effects of cracks on soil water (Zou et al., 2013; Wei et al., 2006; Zhang et al., 2007), very few reports about the temporal and spatial changes in the characteristics of the soil surrounding the cracks/gaps and the effects of cracks on plant growth and development have been available. In the subsided areas, the newly formed micro-geomorphic features such as subsided hole, subsided cave, and cracks (gap) etc. caused by mining subsidence also bring about corresponding changes in the spatial structures of soil. The changes in the spatial factors that affect the soil characteristics certainly cause the spatial changes in the physicochemical properties of the surrounding soil (Zhao et al., 2010). The cracks (gaps) in the soil lead to the increase in the evaporation area and evaporation intensity of soil in subsided areas. The disturbance of cracks on soil water affects not only soil physicochemical properties but also the characteristics of soil microorganisms (Li et al., 2014) and ultimately affects the growth of plants. Thus, strengthening the studies in this aspect will be beneficial for complete understanding and evaluating the effects of coal mining on the regional environment.

In this study, by choosing the farmland located in the subsided area of Zhaogu Second Coal Mine of Jiaozuo Coal Group, Henan Province, China, as the research object, a field investigation and laboratory analysis experiment was conducted to explore effect of surface cracks caused by coal mining on the soil characteristics and crop growth in different locations surrounding the cracks, which may provide the theoretical basis for reclamation/management of farmland and for improvement of the productivity of farmland in coal mining subsidence area.

\section{Materials and methods}

\section{Site description}

In this experiment, the subsided area of the Zhaogu Second Coal Mine of Jiaozuo Coal Group, Henan province, China, was selected as the studied area (Fig. 1). The mean annual atmosphere temperature was $14^{\circ} \mathrm{C}$, the mean annual precipitation was $603-713$ $\mathrm{mm}$ and the mean water evaporation intensity was $2039 \mathrm{~mm}$. The air temperature and precipitation during the wheat growing season are shown in Table 1 and Figure 2, respectively. During the recent years, the large-scale coal mining has caused serious damage to the local farmland. Approximately $40 \mathrm{hm}^{2}$ subsided area have been formed, 
among which, approximately $30 \mathrm{hm}^{2}$ was the stable subsided region and $10 \mathrm{hm}^{2}$ was the dynamically subsided region (Xu et al., 2015). There are many cracks (gaps) caused by surface subsidence in the dynamically subsided region, which led to the serious loss of soil water and nutrients. This seriously affected not only the quality of soil environment but also the regional agricultural production.

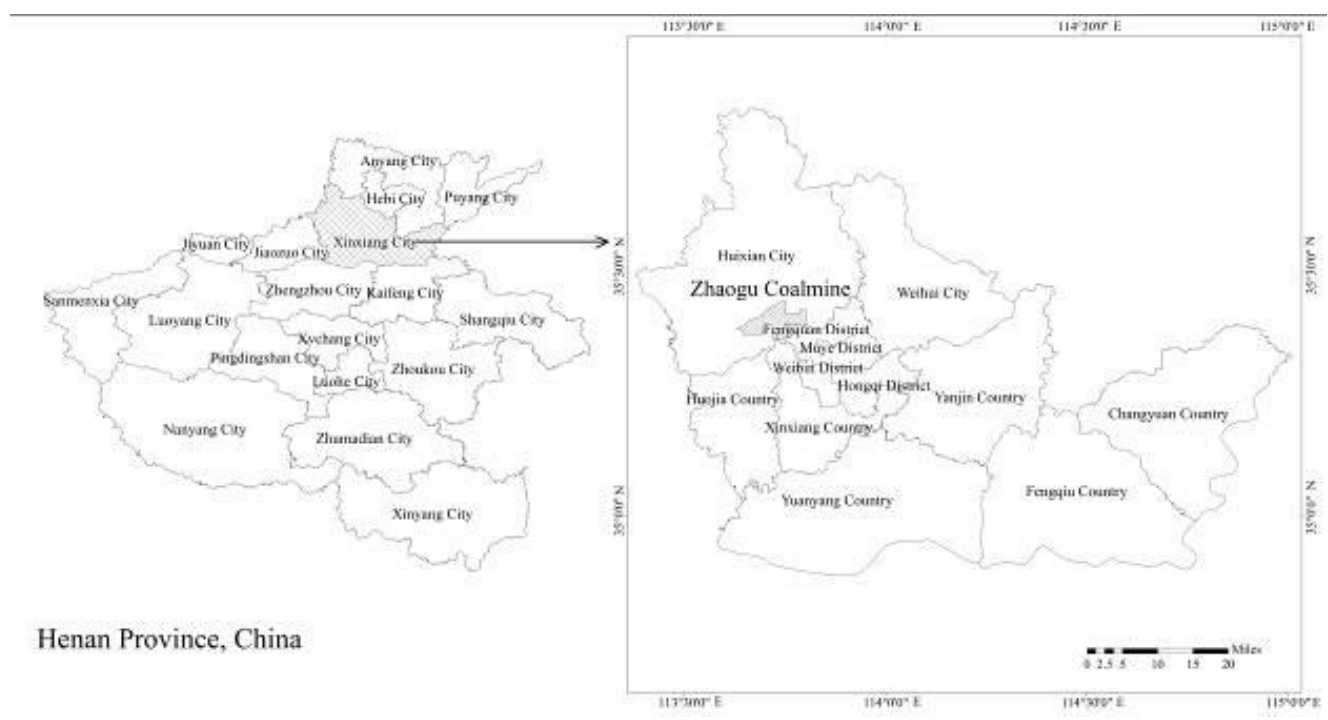

Figure 1. The location of the sampling site.

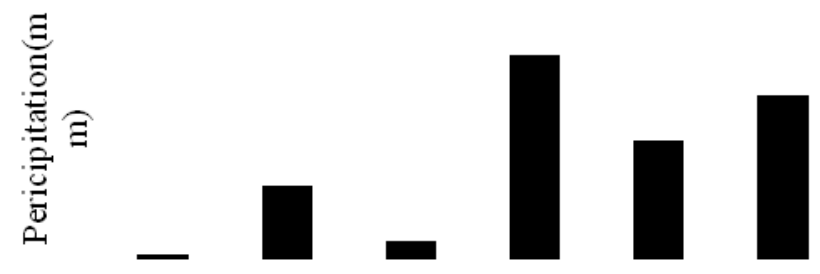

Figure 2. Distribution of the monthly precipitation at the study area

Table 1. Distribution of the monthly air temperature at the study area

\begin{tabular}{|l|l|l|l|l|l|l|}
\hline Months & Jan. & Feb. & Mar. & Apr. & May & Jun. \\
\hline $\begin{array}{l}\text { High } \\
\text { temperature }\end{array}$ & 16.9 & 14.9 & 28.5 & 29.0 & 38.2 & 39.7 \\
\hline $\begin{array}{l}\text { Low } \\
\text { temperature }\end{array}$ & -5.5 & -9.1 & 1.4 & 7.6 & 10.7 & 19.4 \\
\hline Average & 2.9 & 2.6 & 12.7 & 17.1 & 29.7 & 32.0 \\
\hline
\end{tabular}

\section{Sampling methods}

This experiment was conducted in the subsided farmland in Zhaogu Second Coal Mine from February to June, 2014. The soil was silty clay loam. For studying the effects of subsided cracks on the crop growth, two vertical, obviously well-developed cracks in this subsided area were selected as the studied objects. Among which, the 
length, width and depth of larger crack named Crack 1(C-1) were $45 \mathrm{~m}, 5-10 \mathrm{~cm}$ and $200 \mathrm{~cm}$, respectively. The length, width and depth of smaller crack named Crack 2 (C2) were approximately $25 \mathrm{~m}, 1-3 \mathrm{~cm}$ and $100 \mathrm{~cm}$, respectively. These cracks had been formed for about 30 days. Soil and plants sample in the locations with 30, 60, 90 and $120 \mathrm{~cm}$ from the edges of the cracks were collected. The physicochemical properties of soil and physiological and ecological characteristics of wheat were examined. The soil and plant samples in the locations with different distances from the edge of cracks collected three times at each side of the cracks with the total of 6 times of collecting these samples.

The experimental crop was winter wheat (Bainong Aikang 58) with the mean planting density of $1.8 \times 10^{6}$ plants $/ \mathrm{hm}^{2}$. At both the jointing and the flowering stages, soil samples at $0-30 \mathrm{~cm}$ and $30-60 \mathrm{~cm}$ layers were collected were collected by using auger boring at each sampling point. These soil samples were immediately put into the aluminum box and sealed completely, and then brought back to laboratory for subsequent analysis.

\section{The measurement parameters and methods}

The measurements of soil water content, soil available nitrogen content and soil respiration rate: the soil water content was measured with the method of weighting after being dried. The soil available nitrogen content was measured with alkaline hydrolysis diffusion method. Soil respiration rate was measured with EGM-4 portable soil respirator (PP Systems, Amesbury, MA, USA) at each sampling point. Samples at each distance point were collected three times.

Measurement of the activities of soil enzymes: the soil samples within the $0-30 \mathrm{~cm}$ layer were collected at the locations of 30,60, 90 and $120 \mathrm{~cm}$ from the edges of the cracks, respectively. The collected samples were fully blended and then put into the ice bottle, immediately brought back to laboratory and stored at $-20^{\circ} \mathrm{C}$ freezer. These soil samples were used for subsequent analysis of the activities of soil enzymes. The urease activity was assayed with sodium phenate colorimetry. The invertase activity was assayed with 3,5-dinitrosalicylic acid colorimetry. A total of 6 replicate soil samples were measured at each location (Yao et al., 2006).

Measurements of photosynthesis rate and chlorophyll content: the net photosynthesis rate of wheat leaves was measured with LI-6400 Portable Photosynthesis System (LICOR, Lincoln, NE, USA) in 9:00-11:00 AM in the morning. Chlorophyll content of the leaves of the same plants was measured with SPAD-502 chlorophyll meter (Minolta Co., Ltd, Osaka, Japan). A total of 6 replicate plant samples were measured at each location.

Measurements of Grain Yield and Yield Trials: At the mature stage of wheat, at each sampling point, the grain yield of wheat at two lines with the length of $1 \mathrm{~m}$ were randomly selected to assess the yield capacity. The assessment was repeated three times. At the same time, at each sampling point, a total of 30 wheat plants were selected randomly and used to measure the plant height, weight per stem, number of grain, number of fertile spikelet, the number of infertile spikelet and the 1000-grain weight.

Data were statistically analyzed using Microsoft Excel 2000. The differences in the effects between treatment groups were compared by t-test with $\mathrm{P}<0.05$ being regarded statistically significant. 


\section{Results}

\section{Effects of the surface cracks on characteristics of soil water and fertility}

The surface cracks caused by mining subsidence not only destroyed soil structure but also led to the loss of soil water and soil fertilizers. During the jointing stage of winter wheat (20 days after the formation of the cracks), the cracks had no significant effects on the available nitrogen content of soil but significantly affected soil water content in the soil surrounding cracks. Cracks with different widths caused the different effects on soil water content. Within $0-30 \mathrm{~cm}$ soil layer, C-1 significantly affected the soil water content within $0-60 \mathrm{~cm}$ from the cracks. When the distance from the cracks was over $60 \mathrm{~cm}$, the cracks had no significant effects on soil water content. The range of soil water content affected by C-2 was only $0-30 \mathrm{~cm}$. Within the soil layer of $30-60 \mathrm{~cm}, \mathrm{C}-2$ had no effects on soil water content. C-1 had significant effects on soil water content only within 0-30 $\mathrm{cm}$ from the cracks. During the flowering stage, within the soil layer of 0-30 cm, C-1 and $\mathrm{C}-2$ both significantly reduced soil water content and available nitrogen content in the surrounding soil within 0-60 $\mathrm{cm}$ and 0-30 $\mathrm{cm}$ from the cracks, respectively (Figs. 3 and 4). Within the soil layer of $30-60 \mathrm{~cm}$, both C-1 and C-2 significantly reduced soil water content and available nitrogen content in the surrounding soil within $0-30 \mathrm{~cm}$ from the cracks. When the distance from the cracks was over $30 \mathrm{~cm}$, the cracks had no significant effects on soil water content and available nitrogen content.
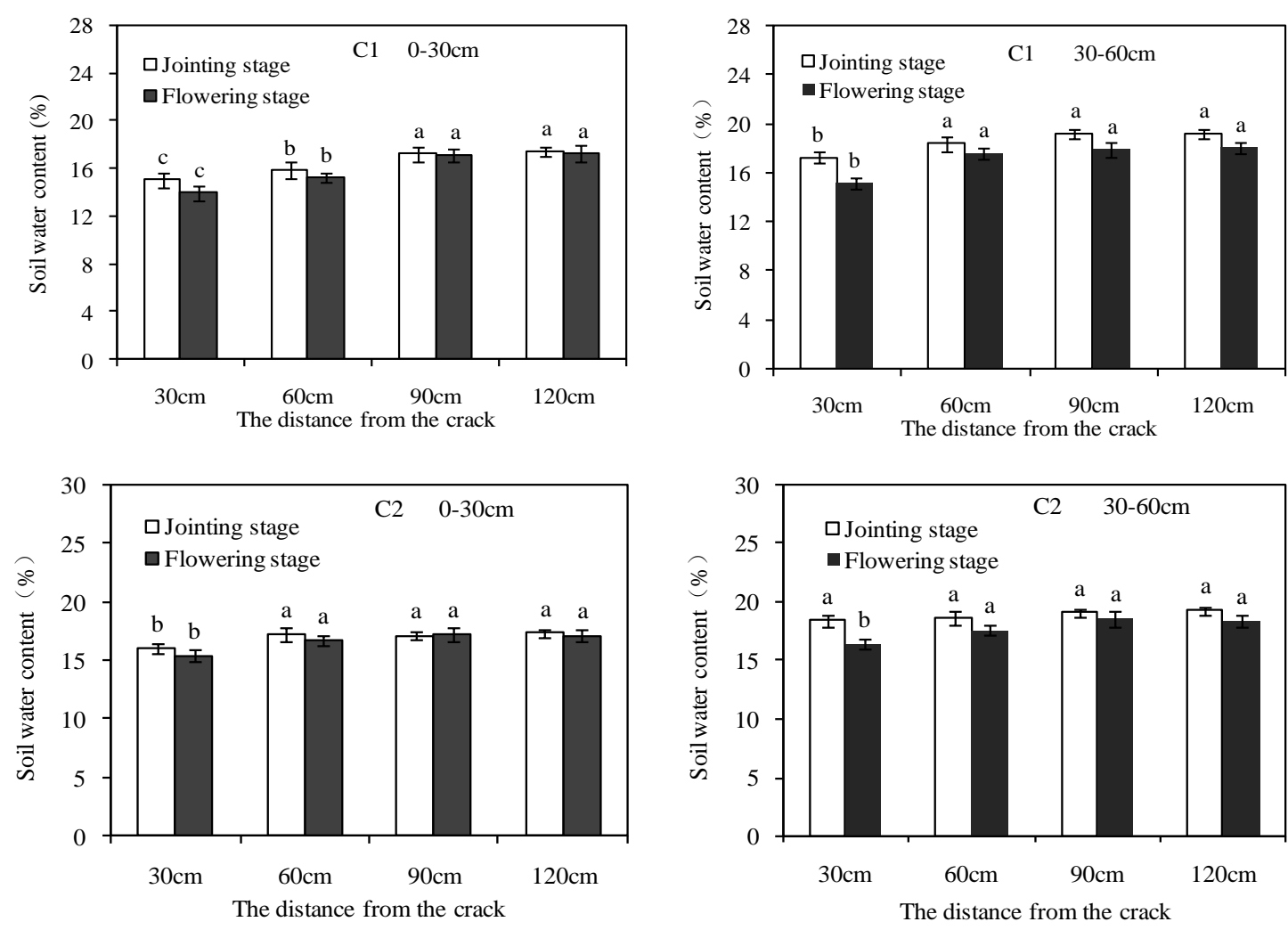

Figure 3. Effect of surface cracks on soil water content in coal mining subsided area. $C-1$ : larger crack with a $45 \mathrm{~m}$ in length, $5-10 \mathrm{~cm}$ in width and $200 \mathrm{~cm}$ in depth; $C$-2: smaller crack with a $25 \mathrm{~m}$ in length, $2-5 \mathrm{~cm}$ in width and $100 \mathrm{~cm}$ in depth. Vertical bars represent $S E$ of the mean. For a given growth stage, mean values followed by the same letter did not differ significantly $(p<0.05)$. 

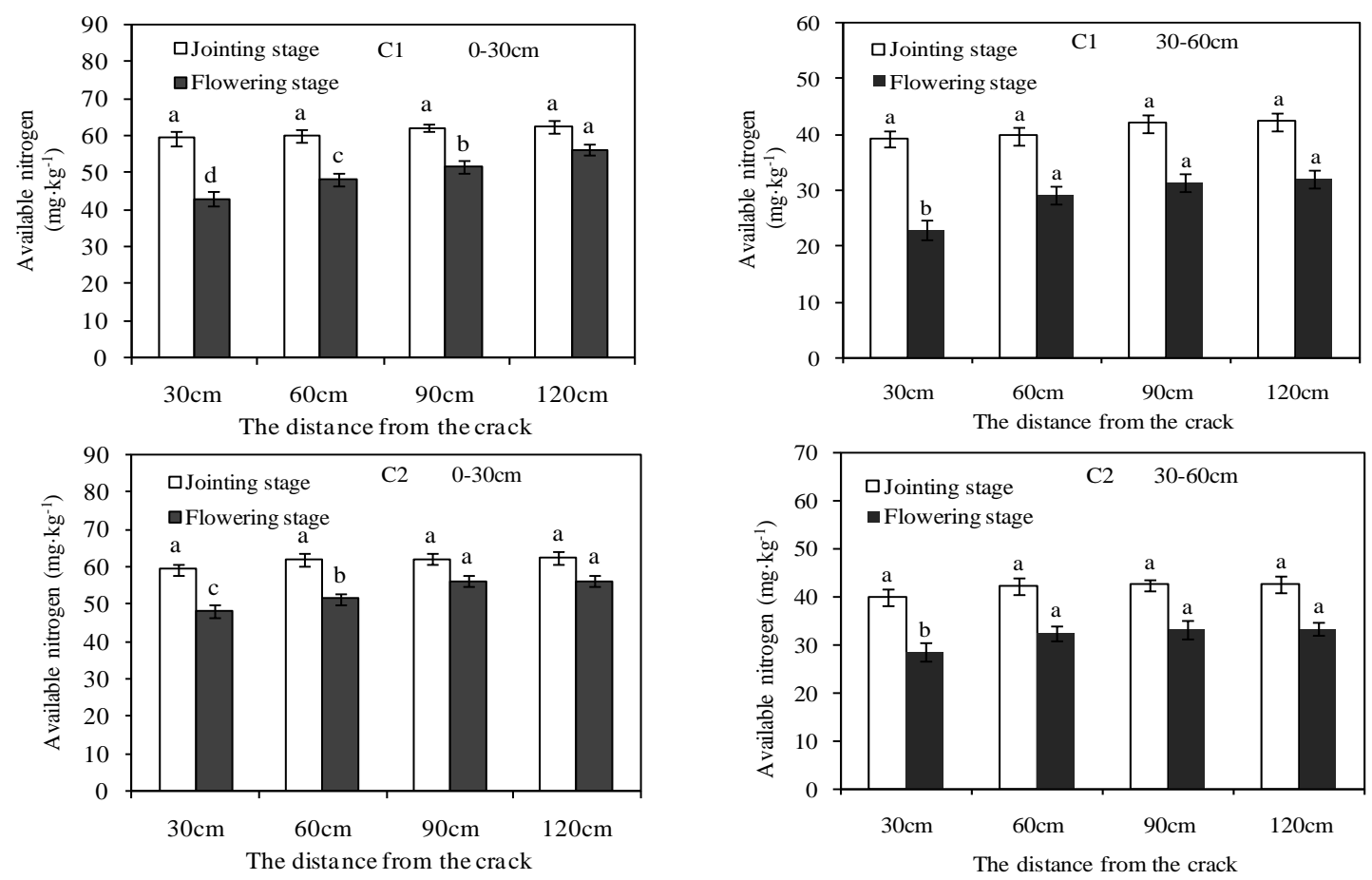

Figure 4. Effect of surface cracks on available nitrogen content in coal mining subsided area. $C$-1: larger crack with a $45 \mathrm{~m}$ in length, $5-10 \mathrm{~cm}$ in width and $200 \mathrm{~cm}$ in depth; $C$-2: smaller crack with a $25 \mathrm{~m}$ in length, $2-5 \mathrm{~cm}$ in width and $100 \mathrm{~cm}$ in depth. Vertical bars represent SE of the mean. For a given growth stage, mean values followed by the same letter did not differ significantly $(p<0.05)$.

\section{Effects of subsided cracks on characteristics of soil microorganisms}

The characteristics (such as the activities of soil enzymes and soil respiration rate) of soil microorganisms are very sensitive to the changes in soil environment. Soil respiration rate reflects, in a large extend, the metabolic intensity of soil organic matters and the transformation/supply capacity of soil nutrients. During the jointing and flowering stages, the surface cracks inhibited the respiration rate of the surrounding soil, the closer the soil from the cracks was, the lower the soil respiration rate was. For C-1, the range within which it inhibited soil respiration rate was $0-60 \mathrm{~cm}$. When the distance from the cracks was over $60 \mathrm{~cm}$, its inhibition on soil respiration rate was not significant. The range within which $\mathrm{C}-2$ inhibited soil respiration rate was $0-30 \mathrm{~cm}$. When the distance from the cracks was over $30 \mathrm{~cm}$, its inhibition was no longer significant (Fig. 5)

The subsided cracks had significant effects on the activities of both urease and invertase (Fig. 6). Within the distance of 0-30 $\mathrm{cm}$ from cracks, the cracks caused maximal inhibition on the activities of soil enzymes. With increasing the distance from crack, this inhibition was gradually reduced. However, during different stages, different soil enzymes performed differently. During the jointing stage of winter wheat, C-2 had no significant inhibition on the activities of both urease and invertases. The range within which $\mathrm{C}-1$ caused inhibition on the activities of two enzymes was 0-60 $\mathrm{cm}$. When the distance from the cracks was over $60 \mathrm{~cm}$, its inhibitory effects were no longer significant. During the flowering stage, the ranges within which $\mathrm{C}-1$ and C-2 caused 
inhibition on the activity of inverase were both $0-60 \mathrm{~cm}$. When the distance from the cracks was over $60 \mathrm{~cm}$, their inhibitory effects on invertase were no longer significant. The range within which $\mathrm{C}-1$ caused inhibition on the activity of urease was $0-60 \mathrm{~cm}$ while such range for $\mathrm{C}-2$ was $0-30 \mathrm{~cm}$.
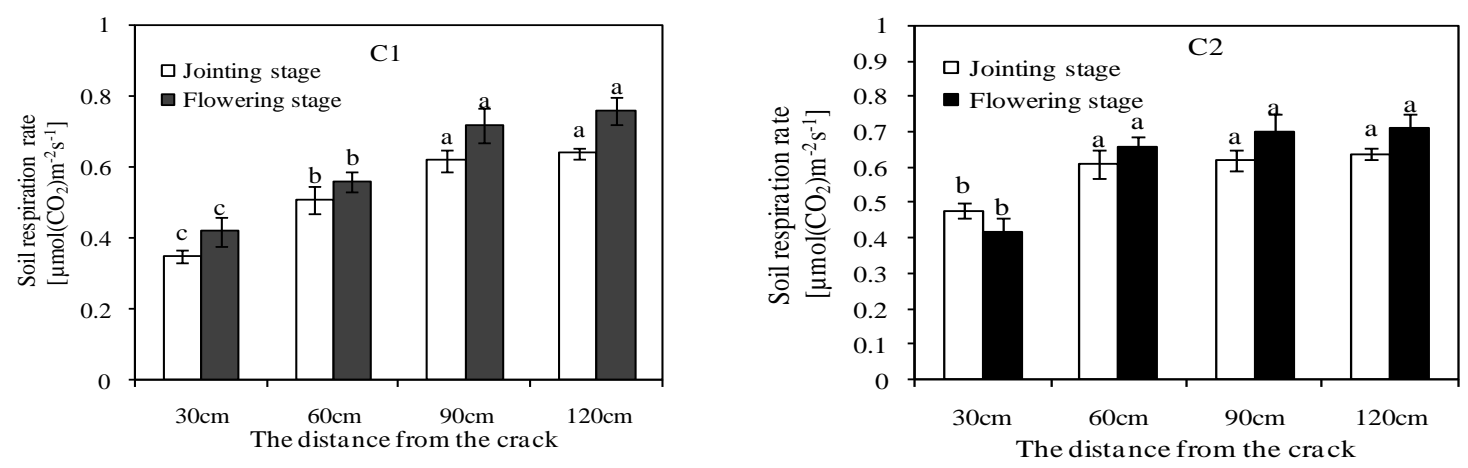

Figure 5. Effect of surface cracks on soil respiration rate in coal mining subsided area. C-1: larger crack with a $45 \mathrm{~m}$ in length, $5-10 \mathrm{~cm}$ in width and $200 \mathrm{~cm}$ in depth; $C$-2: smaller crack with a $25 \mathrm{~m}$ in length, $2-5 \mathrm{~cm}$ in width and $100 \mathrm{~cm}$ in depth. Vertical bars represent $S E$ of the mean. For a given growth stage, mean values followed by the same letter did not differ significantly $(p<0.05)$.
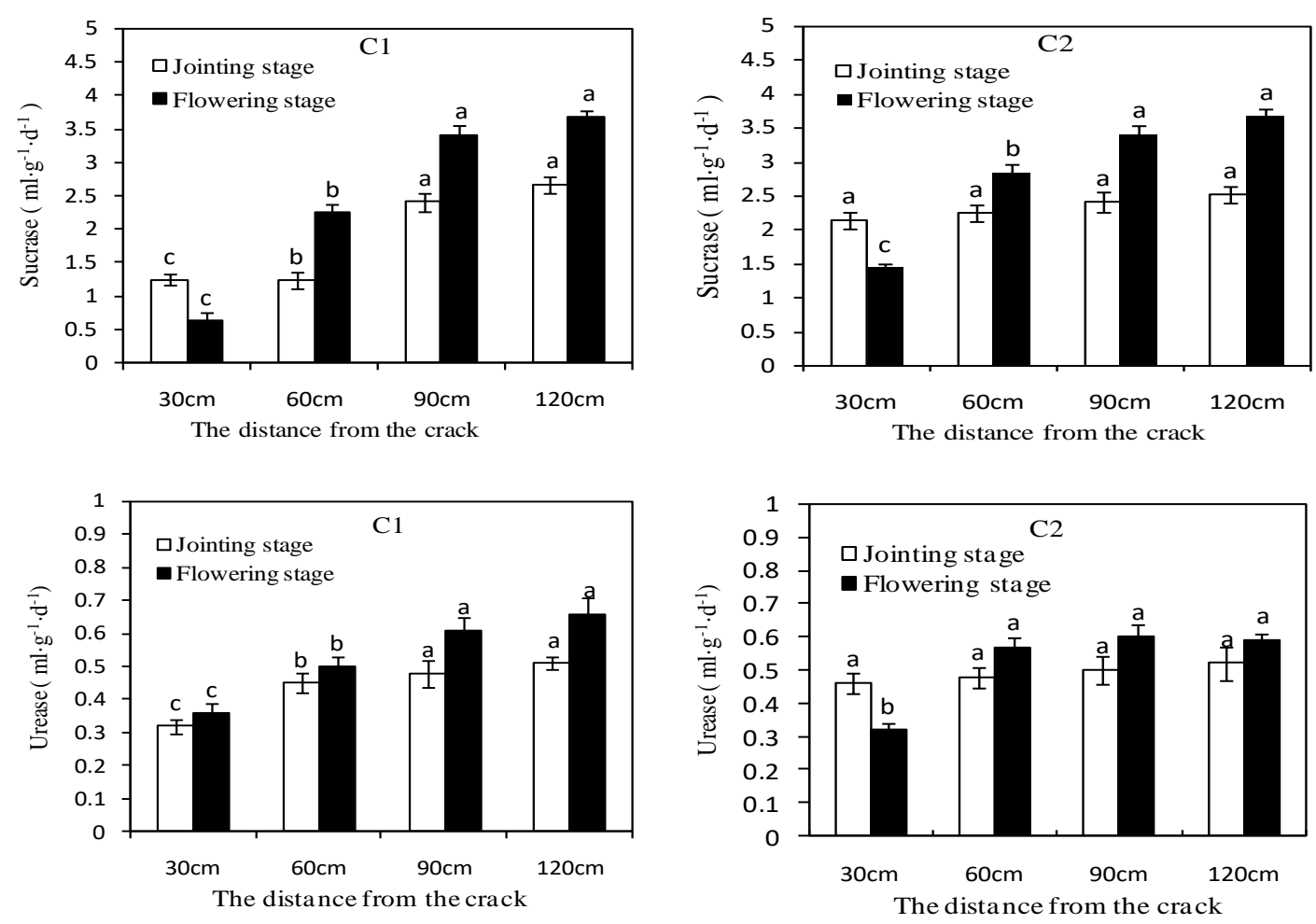

Figure 6. Effect of surface cracks on soil enzyme activities in coal mining subsided area. $C$-1: larger crack with a $45 \mathrm{~m}$ in length, $5-10 \mathrm{~cm}$ in width and $200 \mathrm{~cm}$ in depth; $C$-2: smaller crack with a $25 \mathrm{~m}$ in length, $2-5 \mathrm{~cm}$ in width and $100 \mathrm{~cm}$ in depth. Vertical bars represent SE of the mean. For a given growth stage, mean values followed by the same letter did not differ significantly $(p<0.05)$. 


\section{Effects of subsided cracks on chlorophyll content of wheat leaves and photosynthetic characteristics}

Surface cracks affect physiological characteristics of plant via disturbing the physicochemical properties and microbial characteristics of soil. The chlorophyll content of plant leaves and photosynthetic characteristics are the two important physiological characteristics. During jointing and flowering stages, within $30 \mathrm{~cm}$ from the crack, the chlorophyll content of wheat leaves was lowest. When the distance from the crack was over $30 \mathrm{~cm}$, the differences in the chlorophyll content of wheat leaves were no longer significant (Fig. 7). The photosynthetic rates of wheat leaves were different during different stages. During the jointing stage, both C-1 and C-2 caused significant inhibition on photosynthetic rates within $0-30 \mathrm{~cm}$ from the crack. When the distance from the crack was over $30 \mathrm{~cm}$, cracks had no significant effects of photosynthetic rate of wheat. During the flowering stage, C-1 caused significant inhibition on photosynthetic rate of wheat within the distance of $0-60 \mathrm{~cm}$ from the crack while C-2 caused significant inhibition on photosynthetic rate of wheat leaves within the distance of 0-30 cm from the crack (Fig. 7).
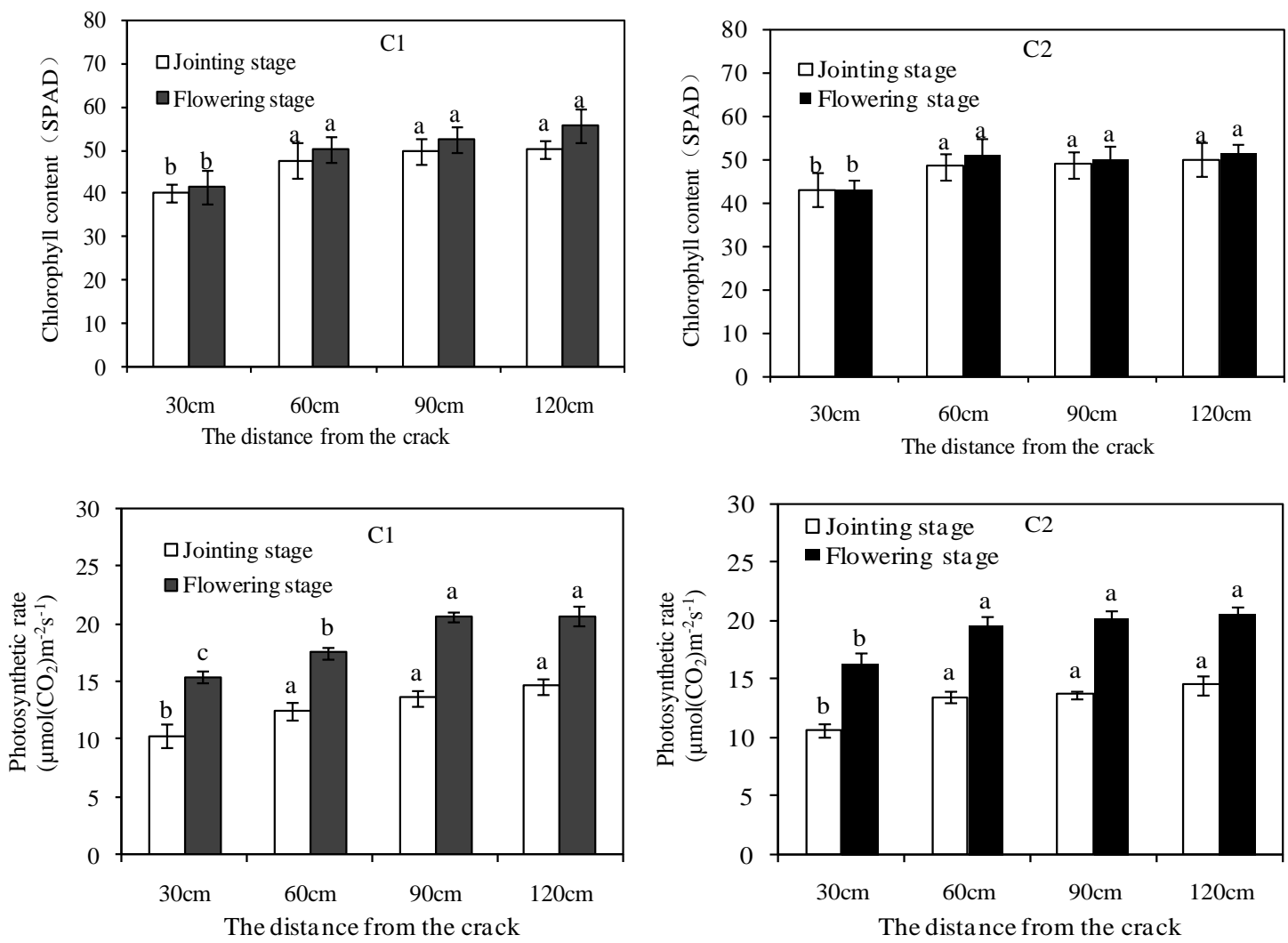

Figure 7. Effects of the surface cracks on chlorophyll content and photosynthetic rate of wheat in coal mining subsided area. C-1: larger crack with a $45 \mathrm{~m}$ in length, $5-10 \mathrm{~cm}$ in width and 200 $\mathrm{cm}$ in depth; C-2: smaller crack with a $25 \mathrm{~m}$ in length, 2-5 cm in width and $100 \mathrm{~cm}$ in depth. Vertical bars represent $S E$ of the mean. For a given growth stage, mean values followed by the same letter did not differ significantly $(p<0.05)$. 


\section{Effects of surface cracks on the yield trail of wheat}

It can be seen from Table 2 that surface cracks had different effects on various yield traits of wheat. Both C-1 and C-2 lowered plant height, weight per stem, and grain number but increased the number of infertile spikelet of wheat within $0-60 \mathrm{~cm}$ from cracks. When the distance from the crack was over $90 \mathrm{~cm}$, both C-1 and C-2 had no effects on plant height, weight of single stem, the number of infertile spikelet and the grain number. Both C-1 and C-2 had no significant effects on 1000-grain weight. However, C-1 significantly reduced the number of fertile spikelet and grain yield of wheat within the distance of $0-90 \mathrm{~cm}$ from the crack. C-2 significantly reduced the number of fertile spikelet and grain yield of wheat within the distance of $0-60 \mathrm{~cm}$ from the crack. Compared with the grain yield of wheat at the distance of $120 \mathrm{~cm}$ from cracks, C-1 and C-2 reduced grain yield of wheat at $30 \mathrm{~cm}$ from the cracks by $53.3 \%$ and $34.8 \%$, respectively.

Table 2. Yield traits of wheat in different locations away from the crack $( \pm$ S.E.)

\begin{tabular}{|c|c|c|c|c|c|}
\hline \multirow{2}{*}{} & \multicolumn{4}{c|}{ Distance from the crack (cm) } \\
\cline { 3 - 6 } & & 30 & 60 & 90 & 120 \\
\hline \multirow{4}{*}{ Items } & Plant height(cm) & $65.1 \pm 1.2 \mathrm{c}$ & $70.2 \pm 1.4 \mathrm{~b}$ & $73.8 \pm 1.1 \mathrm{a}$ & $74.5 \pm 1.1 \mathrm{a}$ \\
\cline { 2 - 6 } & Spike number & $249.4 \pm 9.2 \mathrm{~d}$ & $306.8 \pm 4.3 \mathrm{c}$ & $396.4 \pm 5.2 \mathrm{~b}$ & $442.8 \pm 8.7 \mathrm{a}$ \\
\cline { 2 - 6 } & Weight per stem $(\mathrm{g})$ & $1.12 \pm 0.08 \mathrm{c}$ & $1.56 \pm 0.06 \mathrm{~b}$ & $1.72 \pm 0.05 \mathrm{a}$ & $1.76 \pm 0.03 \mathrm{a}$ \\
\cline { 2 - 6 } & Infertile spikelet & $2.1 \pm 0.10 \mathrm{a}$ & $1.9 \pm 0.08 \mathrm{~b}$ & $0.7 \pm 0.03 \mathrm{c}$ & $0.6 \pm 0.10 \mathrm{c}$ \\
\cline { 2 - 6 } & Grain number per ear & $26.4 \pm 1.1 \mathrm{c}$ & $30.2 \pm 1.8 \mathrm{~b}$ & $34.5 \pm 1.4 \mathrm{a}$ & $35.3 \pm 1.38 \mathrm{a}$ \\
\cline { 2 - 6 } & Thousand seed weight $(\mathrm{g})$ & $36.8 \pm 1.1 \mathrm{a}$ & $37.1 \pm 1.3 \mathrm{a}$ & $37.3 \pm 0.9 \mathrm{a}$ & $36.8 \pm 0.6 \mathrm{a}$ \\
\cline { 2 - 6 } & Grain yield $\left(\mathrm{kg} \cdot \mathrm{m}^{-2}\right)$ & $0.21 \pm 0.02 \mathrm{~d}$ & $0.36 \pm 0.02 \mathrm{c}$ & $0.39 \pm 0.03 \mathrm{~b}$ & $0.45 \pm 0.04 \mathrm{a}$ \\
\hline \multirow{5}{*}{ C-2 } & Plant height $(\mathrm{cm})$ & $68.1 \pm 1.4 \mathrm{c}$ & $72.2 \pm 1.2 \mathrm{~b}$ & $74.6 \pm 1.2 \mathrm{a}$ & $74.4 \pm 1.2 \mathrm{a}$ \\
\cline { 2 - 6 } & Spike number & $289.4 \pm 9.2 \mathrm{c}$ & $396.8 \pm 4.3 \mathrm{~b}$ & $440.4 \pm 4.2 \mathrm{a}$ & $446.8 \pm 7.1 \mathrm{a}$ \\
\cline { 2 - 6 } & Weight per stem $(\mathrm{g})$ & $1.32 \pm 0.08 \mathrm{c}$ & $1.66 \pm 0.06 \mathrm{~b}$ & $1.71 \pm 0.05 \mathrm{a}$ & $1.74 \pm 0.01 \mathrm{a}$ \\
\cline { 2 - 6 } & Infertile spikelet & $1.9 \pm 0.10 \mathrm{a}$ & $1.9 \pm 0.1 \mathrm{a}$ & $0.6 \pm 0.06 \mathrm{~b}$ & $0.7 \pm 0.11 \mathrm{~b}$ \\
\cline { 2 - 6 } & Grain number per ear & $28.2 \pm 1.1 \mathrm{c}$ & $32.6 \pm 1.6 \mathrm{~b}$ & $35.2 \pm 1.1 \mathrm{a}$ & $35.6 \pm 1.21 \mathrm{a}$ \\
\cline { 2 - 6 } & Thousand seed weight $(\mathrm{g})$ & $36.1 \pm 1.1 \mathrm{a}$ & $37.8 \pm 1.0 \mathrm{a}$ & $37.4 \pm 0.4 \mathrm{a}$ & $37.1 \pm 0.4 \mathrm{a}$ \\
\cline { 2 - 6 } & Grain yield $\left(\mathrm{kg} \cdot \mathrm{m}^{-2}\right)$ & $0.28 \pm 0.03 \mathrm{~d}$ & $0.35 \pm 0.02 \mathrm{~b}$ & $0.44 \pm 0.04 \mathrm{a}$ & $0.46 \pm 0.05 \mathrm{a}$ \\
\hline
\end{tabular}

Mean values followed by different small letters in the same line indicate significant difference at 0.05 level.

\section{Discussions}

\section{Effects of surface cracks on the characteristics of soil water and fertilizers}

Soil cracks cause extremely important effects on the transport process of water and solutes in soil. Coal mining subsidence leads to the formation of cracks (gaps) with different widths on the ground surface, which makes the rainfall to more easily penetrate into underground and thus, reduces the water supply to soil. During the nonraining periods, the crack increases the contact area between soil and external environment and accelerates the lateral evaporation of soil water and exacerbates the loss of water from the soil. Both the reduced water supply and the increased evaporation rate certainly lead to the reduction in soil water content. Furthermore, the vertical cracks (gaps) also weaken the total water-holding capacity of soil. The combined actions of these factors reduce soil water content to different extends (Li et al., 2011). In this study, the result of the investigation on water contents in soil in different spatial 
locations in the subsided area indicates that the cracks significant reduce soil water content in soil surrounding the cracks but the affecting ranges of cracks with different sizes on soil water content varied. The affecting range of the larger crack was larger than that of smaller crack.

The changes in soil nutrients are closely related to the migration of soil water. In the coal mining subsided area, due to the formation of many cracks (gaps) on the ground surface, many nutritional elements in the soil can more easily leak with the direct runoff along cracks during raining, which, in turn, cause the deficiency of soil nutrients, degrade soil environmental quality and seriously affect crop growth (Zhao et al., 2010). In this study, we measured the available nitrogen contents in soils with different distances from the cracks. The results indicated that in the early stage of the crack formation (at the jointing stage of wheat), because of the lack of raining, the available nitrogen content in soil was not changed largely. During the flowering stage, the cracks significantly reduced available nitrogen content in the soil surrounding the cracks. The closer the distance from the crack was, the lower the available nitrogen content in soil was. The effects of the larger cracks on the available nitrogen content in soil were larger than those of the smaller cracks.

\section{Effects of surface cracks on of soil microorganisms}

The characteristics of soil microorganisms, including microbial quantity, activities of soil enzymes and soil respiration etc, are very sensitive to the changes in soil ecological quality and are generally used to evaluate the supply capacity of soil nutrients and soil quality (Zhou and Ding, 2007). Du et al. (2013) reported that surface cracks caused by coal mining obviously reduced microbial quantities and activities of soil enzymes, and also altered the compositions and structure of microbial community in the rhizosphere of Artemisia ordosias. Among different indicators reflecting the characteristics of soil microorganisms, soil respiration rate is the most sensitive one to respond the status of soil water and soil nutrients (Singh et al., 1977; Zheng et al., 2014). In this study, subsided cracks reduced the contents of water and available nitrogen in the soils surrounding the cracks and, at the same time, also significantly reduced soil respiration rate.

All the biochemical processes taking place in the soil are carried out and accomplished by soil enzymes (Zhou and Ding, 2007). Soil enzymes are very sensitive to the changes caused by environmental factors and exhibited quite well the characteristics of timeliness. Most of soil enzymes are mainly derived from soil microorganisms. Soil structures and the status of soil water and nutrients all cause important effects on soil microorganisms. The changes in soil physicochemical properties and in the quantitation of soil microorganisms certainly lead to the directional changes in the activities of the soil enzymes (Noah et al., 2003). For instance, the study by Liu et al (2006) indicated that the activities of both soil invertase and urease were highly and positively correlated with the available nitrogen. In this study, the results of the investigation on the activities of invertase and urease in the soils surrounding the cracks also confirmed the above-mentioned results, i.e. the cracks significantly reduced soil available nitrogen content, which, in turn, affected the activities of soil enzymes. Thus, the activities of both invertase and urease in soil were also significantly reduced. 


\section{Effects of surface cracks on physiological characteristics and grain yield trials of wheat}

Cultivation of crops requires the high soil quality and the proper landform of farmland. The destroying soil environment will affect the cycling processes of water and nutrients in soil and finally cause serious loss of crop yield (Ma et al., 2014). It has been reported that mine subsidence in Illinois, USA, caused a significantly lower corn yield in subsidence areas (Darmody et al., 1989, 1992, 2014). Surface subsidence and cracks caused by coal mining destroyed the stability and integrality of soil structure. Water and fertilizers easily leak and loss along with the cracks, resulting in increasing degeneration of soil quality. Furthermore, due to the lack of scientific management, proper application of fertilizers and irrigation measures in the subsided area, the poor soil quality is further exaggerated. The contents of water and nutrients in soil are the key factors affecting plant growth. Their levels will directly affect the physiological and ecological characteristics and the yield of crops (Cao et al., 2009). Among which, chlorophyll content of leaves somehow reflects the nitrogen level of plants, which is positively correlated with the soil nitrogen content (Guan et al., 2000). The present study also indicated that changes in chlorophyll content of leaves was consistent with the changes in available nitrogen content in soil, i.e. when the soil was closer to the cracks, the content of the available nitrogen in soil was more significantly reduced and, at the same time, chlorophyll content of wheat leaves was also significantly reduced. These results are the same as those of $\mathrm{Xu}$ et al. (2015). Photosynthesis is one of important physiological characteristics of plant and is limited by both the internal factors and external environmental conditions. Soil water and nitrogen are two important environmental factors frequently limiting for plant growth. Water and nitrogen stresses will inhibit photosynthesis and the growth of plant (He et al., 2010). Increasing soil nitrogen content can not only significantly increase chlorophyll content of plant leaves but can also improve the photosynthetic characteristics of crops and increase the grain number and grain weight of wheat (Zhang et al., 2005). In this study, subsided cracks significantly affected the contents of water and available nitrogen in soil and also affected plant's uptake of trients and water. Thus, plant photosynthesis was also significantly affected. The growth and yield of plant are closely related to the accumulation of photosynthates. The closer to cracks were, the greater the effect on photosynthesis of wheat was. Thus, the plant height, grain number and weight per stem were all significantly reduced. The deficiency in photosynthetic capability finally led to the reduction in grain yield of crop. A recent study by $\mathrm{Hu}$ et al.indicated that in the eastern plains of China, the overlapping of coal resources and cropland occupied a total area of $1.33 \times 10^{5} \mathrm{~km}^{2}$, accounting for $31.93 \%$ of the total cropland area. It is estimated that by 2020 , the accumulative total area of cropland destroyed by continuing coal mining in that area may reach as high as $3.83 \times 10^{3}$ $\mathrm{km}^{2}$, leading to the reduction of grain yield by $9.63 \times 10^{8} \mathrm{~kg}$ and an increase in number of landless farmers up to $1.91 \times 10^{6}$ (Hu et al., 2014a). Similar situation may also happen in coal mining areas in Henan province. Therefore, further studies are needed to address this problem and to find effective measures to resolve it. 


\section{Conclusions}

The effect of surface cracks caused by coal mining on the soil characteristics and crop growth was studied in subsided area of Zhaogu coal mine of Jiaozuo Coal Group, China. The results show that surface cracks affected significantly soil characteristics in the soil surrounding the cracks. The larger crack $(\mathrm{C}-1)$ had larger effect ranges on both soil water content and the characteristics of soil microorganisms compared to smaller crack (C-2). Surface cracks lowered significantly chlorophyll content and photosynthetic rate of plant via affecting soil characteristics. During jointing and flowing stage, both $\mathrm{C}-1$ and $\mathrm{C}-2$ caused significant inhibition on photosynthesis of wheat within $0-60 \mathrm{~cm}$ and $0-30 \mathrm{~cm}$ from the cracks, respectively. Surface cracks promoted loss of water and nutrients in the soil surrounding the cracks, which finally led to significant reduction in crop yield. The large crack had stronger effects on grain yield compared to small crack. Therefore, further studies are needed to address this problem and to find effective measures to resolve it.

Acknowledgements. This research was supported by the National Key Research and Development Program of China (2017YFD0301106), the science and technology project of Henan province (162102110169), Innovative Research Team of Henan Polytechnic University (B2017-16), and the science and technology innovation team support plan of universities in Henan (18IRTSTHN008)

\section{REFERENCES}

[1] Brom, J., Nedbal, V., Prochazka, J. (2013): Changes in vegetation cover, moisture properties and surface temperature of a brown coal dump from 1984 to 2009 using satellite data analysis. - Ecological Engineering 43: 45-52.

[2] Cao, C.Y., Zheng, C.L., Li, K.J., Ma, J.Y., Cui, Y.H. (2009): Effect of long-term fertilization on photosynthetic property and yield of summer maize (Zea mays L.). Chinese Journal of Eco-Agriculture 17(6): 1074-1079.

[3] Chen, L.Q., Deng, K.Z., Zhao, Z.H., Xu, S.K., Chai, D.G., Zheng, Z.F., Li, J.M. (1999): Space variation law of physical characteristics about farmland soil due to mining subsidence. - Journal of China Coal Society 24(6): 586-590.

[4] Cheng, W., Bian, Z.F., Dong, J.H., Lei, S.G. (2014): Soil properties in reclaimed farmland by filling subsidence basin due to underground coal mining with mineral wastes in China. Transactions Nonferrous Metals Society of China 24: 2627-2635.

[5] Darmody, R.G., Bauer, R., Barkley, D., Clarke, S., Hamilton, D. (2014): Agricultural impacts of longwall mine subsidence: the experience in Illinois, USA and Queensland, Australia. - International Journal of Coal Science \& Technology 1(2): 207-212.

[6] Darmody, R.G., Hetzler, R.T., Simmons, F.W. (1992): Coal mine subsidence: effects of mitigation on crop yields. - International Journal of Surface Mining, Reclamation and Environment 6(4): 187-190.

[7] Darmody, R.G., Jansen, I.G., Carmer, S.G., Steiner, J.S. (1989): Agricultural impacts of coal mine subsidence: effects on corn yields. - Journal of Environment al Quality 18: 265-267.

[8] Du, T., Bi, Y.L., Gao, F., Lv, W.L. (2013): Effects of surface cracks on the rhizospheric microhabitat of Artemisia ordosica in subsidence area caused by coal mining. - Journal of Coal Science and Engineering (China) 19(2): 231-236.

[9] Guan, Y.X., Lin, B., Ling, B.Y. (2000): Interaction effects of light density and nitrogen on maize leaf pigments, chlorophyll fluorescence and energy transition. - Plant Nutrition and Fertilizer Science 6(2): 152-158. 
[10] He, Z.S., Cai, Z.Q., Cai, C.T. (2010): Effect of water and nitrogen on photosynthetic characteristics and growth of Rauvolfia vomitoria. Chinese Journal of Eco-Agriculture 18(4): 758-764.

[11] Hossain, M.N., Paul, S.K., Hasan, M.M. (2015): Environmental impacts of coal mine and thermal power plant to the surroundings of Barapukuria, Dinajpur, Bangladesh. Environmental Monitoring and Assessment 187(4): 202.

[12] Hu, Z.Q., Yang, G.H., Xiao, W., Li, J., Yang, Y.Q., Yu, Y. (2014a): Farmland damage and its impact on the overlapped areas of cropland and coal resources in the eastern plains of China. - Resources, Conservation and Recycling 86: 1-8.

[13] Hu, Z.Q., Long, J.H., Wang, X.J. (2014b): Self-healing, natural restoration and artificial restoration of ecological environment for coal mining. - Journal of China Coal Society 39(8): 1751-1757.

[14] Kuang, W.L., Deng, Y.F. (2007): Probe into the soil environmental impact of coal mining collapsed area and its prevention and cure measures. - China Safety Science Journal 17(1): 116-120.

[15] Li, L., Wang, Y.X., Wang, W.B. (2010): Effects of mining subsidence on physical and chemical properties of soil in slope land in hilly-gully region of Loess Plateau. - Chinese Journal of Soil Science 41(5): 1237-1240.

[16] Li, W., Chen, L.Q., Zhou, T.J., Zhang, K., Li, L. (2011): Research progress of soil quality in China mining subsidence area. - Coal Science and Technology 39(5): 125-128.

[17] Li, Y.Y., Chen, L.Q., Wen, H.Y., Zhou, T.J., Zhang, T. (2014): Pyrosequencing-based assessment of bacterial community structure in mine soils affected by mining subsidence. - International Journal of Mining Science and Technology 24: 701-706.

[18] Liu, M.Y., Chang, Q.R., Qi, Y.B., An, S.S. (2006): Features of soil enzyme activity under different land uses in Ningnan Mountain area. - Chinese Journal of Eco-Agriculture 14(3): 67-70.

[19] Ma, S.C., Zhang, H.B., Ma, S.T., Li, C.X., Shao, Y. (2014): Effects of tillage on water use efficiency and grain yield of summer maize in sloping farmland in coal-mining subsidence areas. - Journal of Ecology and Rural Environment 30(2): 201-205.

[20] Martinez, R.E., Marquez, J.E., Hòa, H.T., Gieré, R. (2013): Open-pit coal-mining effects on rice paddy soil composition and metal bioavailability to Oryza sativa L. plants in Cam Pha, northeastern Vietnam. - Environmental Science and Pollution Research International 20(11): 7686-98.

[21] Meng, Q.J., Feng, Q.Y., Wu, Q.Q., Meng, L., Cao, Z.Y. (2009): Distribution characteristics of nitrogen and phosphorus in mining induced subsidence wetland in Panbei coal mine, China. - Procedia Earth and Planetary Science 1: 1237-1241.

[22] Moreno-de las Heras, M., Nicolau, J.M., Espigares, T. (2008): Vegetation succession in reclaimed coal-mining slopes in a Mediterranean-dry environment. - Ecological engineering 34: 168-178.

[23] Noah, F., Joshua, P.S., Patricia, A.H. (2003): Variations in microbial community composition through two soil depth profiles. - Soil Biology and Biochemistry 35(1): 167176.

[24] Quan, Z.J., Cheng, H., Yu, Y.J., Zou, X.Y. (2006): Assessment of subsidence impact on vegetation landscape in coal mining area - A case study of Dongda mine in Jincheng City, Shanxi Province. - Journal of Plant Ecology 30(3): 414-420.

[25] Sadhu, K., Adhikari, K., Gangopadhyay, A. (2012): Effect of mine spoil on native soil of Lower Gondwana coal fields: Raniganj coal mines areas, - India International Journal of Environmental Sciences 2(3): 1675-1688.

[26] Singh, J.S., Gupta, S.R. (1977). Plant decomposition and soil respiration in terrestrial ecosystems. - The Botany Review 43(4): 449-528.

[27] Tripathi, N., Singh, R.S., Singh, J.S. (2009): Impact of post-mining subsidence on nitrogen transformation in southern tropical dry deciduous forest, India. - Environmental Research 10: 258-266. 
[28] Wei, J.S., He, X., Hu, C.Y., Wang, J. (2006): Influence of ground collapse caused by coal mining activities on the water characteristics of sandy soil in arid and semi-arid area. Journal of Arid Land Resources and Environment 20(5): 84-88.

[29] Wu, K., Li, L., Wang, X.L., Zhang, L.G., Wang, Z.S., Sun, X.M., (2009): Research of ground cracks caused by fully-mechanized sublevel caving mining based on field survey. - Procedia Earth and Planetary Science 1:1095-1100.

[30] Xu, C.Y., Ma, S.C., Zhang, H.B., Wang, R., Guan, Z.M. (2015): Effect of cracks on soil characteristics and crop growth in subsided coal mining areas. Chinese Journal of EcoAgriculture 23(5): 597-604

[31] Yao, H., Huang, C., (2006): Soil Microbial Ecology and Its Experimental Technique. Beijing: Science Press.

[32] Zhang, F.W., Zhao, H.M., Song, Y.X., Chen, L. (2007): The effect of coal-mining subsidence on water environment in the Shenfu-Dongsheng mining area. Acta Geoscientica Sinica 28(6): 521-527.

[33] Zhang, Q.Y., Li, F.D., Liu, M.Y. (2005): Changing laws of chlorophyll content and photosynthetic rate in winter wheat leaves. - Chinese Journal of Eco-Agriculture 13(3): 95-98.

[34] Zhao, H.M., Zhang, F.W., Song, Y.X., Jing, E.C., Wei, W., Han, Z.T. (2010): Spatial variation of soil moisture contentin mining subsidence areas of Daliuta, Shenmu County, Shaanxi Province. - Journal of Geo-information Science 12(6): 753-760.

[35] Zheng, Y.H., Zhang, Z.G., Hu, Y.B., Yao, D.X., Chen, X.Y. (2014): Seasonal variation of soil respiration and its environmental effect factors on refactoring soil in coal mine reclamation area. - Journal of China Coal Society 39(11): 2300-2306.

[36] Zhou, L.X., Ding, M.M. (2007): Soil microbial characteristics as bioindicators of soil health. - Biodiversity Science 15(2): 162-171.

[37] Zhou, Y., He, X., Xu, J., Liu, J. (2009): Effects of coal mining subsidence on vegetation composition and plant diversity in semi-arid region. - Acta Ecologica Sinica 29(8): 45174525.

[38] Zou, H., Bi, Y.L., Jin, J.J., Zhu, C.W., Peng, X., L,i L.J. (2013): Mining subsidence affected to soil volume-weight and water infiltration law of different vegetation type. Coal Science and Technology 41(3): 125-128. 